\title{
Effects of rapid calcination on properties of calcium-based sorbents
}

\author{
Chang-Feng Yan ${ }^{\mathrm{a}, \mathrm{b}, *}$, John R. Grace ${ }^{\mathrm{a}}, \mathrm{C}$. Jim Lim ${ }^{\mathrm{a}}$ \\ ${ }^{a}$ Department of Chemical \& Biological Engineering, University of British Columbia, Vancouver, Canada V6T $1 Z 3$ \\ ${ }^{\mathrm{b}}$ Guangzhou Institute of Energy Conversion, Chinese Academy of Sciences, Guangzhou 510640, China
}

\section{A R T I C L E I N F O}

\section{Article history:}

Received 15 May 2010

Received in revised form 24 June 2010

Accepted 2 July 2010

\section{Keywords:}

Rapid calcination

Calcium-based sorbents

Foil

Wire mesh

\begin{abstract}
A B S T R A C T
The calcination process may influence subsequent fragmentation, sintering and swelling when CaO derived from limestone acts as a $\mathrm{CO}_{2}$ or $\mathrm{SO}_{2}$-sorbent in combustion, gasification and reforming. Sorbent properties are affected by $\mathrm{CO}_{2}$ partial pressure, total pressure, temperature, heating rate, impurities and sample size. In this study, the effect of calcination heating rate was investigated based on an electrically heated platinum foil. The effects of heating rate (up to $800^{\circ} \mathrm{C} / \mathrm{s}$ ), calcination temperature $\left(700-950{ }^{\circ} \mathrm{C}\right.$ ), particle size (90$180 \mu \mathrm{m}$ ) and sweep gas velocity were investigated. Higher initial heating rates led to lower extents of limestone calcination, but the extents of carbonation of the resulting $\mathrm{CaO}$ were similar to each other. Calcium utilization declined markedly during carbonation or sulphation of $\mathrm{CaO}$ after calcination by rapid heating. Experimental results show that carbonation and calcium utilization were most effective for carbonation temperatures between 503 and $607^{\circ} \mathrm{C}$. Increasing the extent of calcination is not the best way to improve overall calcium utilization due to the vast increase in energy consumption.
\end{abstract}

(c) 2010 Elsevier B.V. All rights reserved.

\section{Introduction}

The increasing use of fossil fuels to meet energy needs has led to higher carbon dioxide $\left(\mathrm{CO}_{2}\right)$ and sulphur dioxide $\left(\mathrm{SO}_{2}\right)$ emissions into the atmosphere. Increasing attention has been focused on chemical looping of limestone involving calcination and carbonation for carbon dioxide separation during combustion, gasification and reforming. Gaseous $\mathrm{CO}_{2}$ reacts with lime to yield calcium carbonate during carbonation

$\mathrm{CaO}+\mathrm{CO}_{2} \rightarrow \mathrm{CaCO}_{3} \quad \Delta H_{298 \mathrm{~K}}=-178 \mathrm{~kJ} / \mathrm{mol}$

and the lime is then regenerated by calcination, i.e.

$\mathrm{CaCO}_{3} \rightarrow \mathrm{CaO}+\mathrm{CO}_{2} \quad \Delta H_{298 \mathrm{~K}}=178 \mathrm{~kJ} / \mathrm{mol}$

Lime derived from calcium-based sorbent (limestone or dolomine) is also commonly utilized to capture $\mathrm{SO}_{2}$ in fluidized bed combustors via

$\mathrm{CaO}+\mathrm{SO}_{2}+\frac{1}{2} \mathrm{O}_{2} \rightarrow \mathrm{CaSO}_{4} \quad \Delta H_{298 \mathrm{~K}}=-426.5 \mathrm{~kJ} / \mathrm{mol}$.

It is important to understand whether the manner in which the calcination takes place affects the subsequent carbonation and sulphation processes. In this paper, we investigate the effects of

\footnotetext{
* Corresponding author. Guangzhou Institute of Energy Conversion, Chinese Academy of Sciences, Guangzhou 510640, China. Tel./fax: + 862087057729.

E-mail address: yancf@ms.giec.ac.cn (C.-F. Yan).
}

calcination rate and conditions on the subsequent performance of calcium-based sorbents.

\section{Calcination}

Calcination of limestone involves five steps:

(1) Heat transfer from the surroundings to the exterior of a particle.

(2) Heat transfer from the external surface to the interior reaction interface.

(3) Heat absorption and thermal decomposition at the reaction interface.

(4) Diffusion of $\mathrm{CO}_{2}$ formed by the reaction through a porous layer of $\mathrm{CaO}$.

(5) Diffusion of $\mathrm{CO}_{2}$ from the particle exterior surface to the surroundings.

Several investigations [1,2] have shown that decomposition of calcium carbonate occurs at a well-defined boundary between the $\mathrm{CaO}$ and $\mathrm{CaCO}_{3}$ phases. This boundary migrates towards the centre of the particle. Dennis and Hayhurst [3] and Silcox et al. [4] used the shrinking core model to predict their experimental results, whereas Borgwardt [5] assumed a homogeneous reaction throughout the sorbent for particles smaller than $90 \mu \mathrm{m}$. Khinast et al. [6] concluded that simple models such as the shrinking core and uniform conversion models only apply in extreme cases. Rao et al. [7] assumed gradual conversion in pellets of size $\sim 6.5 \mathrm{~mm}$, with the mass transfer in the porous shell controlling the reaction. Later, Hu and Scaroni [8] 
observed by SEM analysis different conversion levels inside partially calcined $63 \mu \mathrm{m}$ limestone particles.

Both heat and mass transfer have been found to influence the rate of calcination. Improved thermal conductivity of the selected sweep gas increases the rate of calcination [9]. Previous studies [2,10,11] have indicated that the kinetics of decomposition of calcium-based sorbents depend greatly on the experimental system and conditions.

The porosities of calcined samples vary over a wide range $(0.32$ 0.51 ) depending on the limestone. The apparent activation energies of large limestone particles calcined in thermogravimetric analyzers or in differential reactors at temperatures $<900{ }^{\circ} \mathrm{C}$ range from 79 to $280 \mathrm{~kJ} / \mathrm{mol}[5,7,11-15]$, while the activation energy has been determined to be $209 \mathrm{~kJ} / \mathrm{mol}[16,17]$. Garcýa-Calvo et al. [15] found values from 110 to $194 \mathrm{~kJ} / \mathrm{mol}$ depending on the limestone impurities. These values are higher than those (33 to $92 \mathrm{~kJ} / \mathrm{mol}$ ) obtained in entrained-flow reactors $[4,14,18]$ for particles smaller than $100 \mu \mathrm{m}$ and temperatures up to $1200{ }^{\circ} \mathrm{C}$. Mai [19] attributed the higher activation energies to inadequate sorbent/gas mixing or slow particle heat-up. Results were similar for dehydration of calcium hydroxide. Activation energies between $79 \mathrm{~kJ} / \mathrm{mol}$ [12] and $280 \mathrm{~kJ} /$ mol [13] were higher than $\sim 67 \mathrm{~kJ} / \mathrm{mol}$ obtained in a drop tube reactor $[14,19]$. The activation energy for calcination of Omyacarb limestone, $96 \mathrm{~kJ} / \mathrm{mol}$, was similar to that obtained by other authors under similar experimental conditions. However, values of 36 and $50 \mathrm{~kJ} / \mathrm{mol}$, reported by Fierro et al. [20], were lower than those obtained by other authors.

Khraisha and Dugwell [21] studied the thermal decomposition of a limestone in a thermogravimetric analyzer at heating rates up to $80 \mathrm{~K} / \mathrm{min}$ and temperatures to $950{ }^{\circ} \mathrm{C}$. They also summarized a wide range of data from other workers with activation energies and frequency factors varying from 33 to $4002 \mathrm{~kJ} / \mathrm{mol}$ and $10^{2}$ to $10^{69} \mathrm{~s}^{-1}$, respectively.

Particle size influences the calcination rate. For small particles (1$90 \mu \mathrm{m})$, chemical reaction controls the calcination rate $[5,14]$. Heat transfer becomes important [7] for particles larger than $6 \mathrm{~mm}$. For intermediate size particles, reaction and internal mass transfer are the main resistances controlling calcination. Their relative importance also depends on the pore structure. The calcination rate increases with decreasing particle size because pore diffusion is less important for smaller particles. The relative importance of heat transfer is also greatly influenced by particle size $[6,8,22]$.

From the numerical simulation of $\mathrm{Hu}$ and Scaroni [8], the intraparticle average temperature is lower than the sweep gas temperature, and there are large temperature gradients within the particle, especially for larger particles. Wernick [23] attributed the difference between activation energies of limestones to different calcination temperatures. He proposed that the activation energy is higher at low temperatures. Bischoff [24] found an activation energy of $185 \mathrm{~kJ} / \mathrm{mol}$ in the temperature range between 550 and $800{ }^{\circ} \mathrm{C}$ in moist or dry sweep air, whereas Ar and Dogu [25] obtained values between 410 and $1470 \mathrm{~kJ} / \mathrm{mol}$, depending on the heating rate and gas composition.

\section{Carbonation}

The possibility of using the carbonation reaction to capture $\mathrm{CO}_{2}$ from a gas stream was considered as early as the 19th century [26]. Calcined limestone may be able to remove $\mathrm{CO}_{2}$ in fluidized bed combustion environments and, by subsequent calcination, to produce a nearly pure $\mathrm{CO}_{2}$ stream for sequestration in a chemical looping process [27-30]. This scheme involved a fluidized bed combustorcarbonator where the fuel burned in an excess of lime which, depending on operating conditions, removed $80 \%$ or more of the $\mathrm{CO}_{2}$ and effectively all of the $\mathrm{SO}_{2}$, and a calciner where sorbent was regenerated releasing a gas of high $\mathrm{CO}_{2}$ concentration. However, experimental results indicate a rapid decline in sorbent effectiveness, especially if $\mathrm{SO}_{2}$ is present [31].

Carbonation involves three different processes according to the unreacted shrinking core model, any of which can be rate-controlling:

(1) Mass transfer from the gas phase to the surface.

(2) Diffusion of gaseous reactant inside the particle pores or through the product layer.

(3) Chemical reaction.

The gas-solid $\mathrm{CO}_{2}-\mathrm{CaO}$ reaction proceeds through two ratecontrolling regimes [32,33]. Reaction occurs rapidly by heterogeneous reaction at the surface in the initial stage. A compact layer of product $\mathrm{CaCO}_{3}$ then develops on the outer region of the particle, causing the rate of reaction to decrease due to the diffusion limitation through this layer [33]. The reaction does not proceed to complete conversion of $\mathrm{CaO}$, instead giving ultimate conversions of $70-80 \%$ [34] or up to $90 \%$ [35]. To describe such gas-solid reaction kinetics, various models have been proposed.

Structural limitations prevent the attainment of $100 \%$ conversion. Dedman and Owen [36] obtained a $\mathrm{CO}_{2}$ uptake of about $0.23 \mathrm{~g}$ of $\mathrm{CO}_{2} /$ $\mathrm{g}$ of $\mathrm{CaO}(\sim 30 \%$ conversion $)$ in $30 \mathrm{~min}$ at $600{ }^{\circ} \mathrm{C}$. Bhatia and Perlmutter [34] reached $~ 70 \%$ conversion for 81-137 $\mu \mathrm{m}$ particles. Mess et al. [37] reported $82 \%$ conversion at $1050{ }^{\circ} \mathrm{C}$ and 11.74 atm $\mathrm{CO}_{2}$ pressure after $32 \mathrm{~h}$ for $15-20 \mu \mathrm{m}$ particles. The limitation on total conversion stems essentially from the initial pore size distribution of the $\mathrm{CaO}$ sorbent. Microporous sorbents (pore size $<2 \mathrm{~nm}$ ) are very susceptible to pore blockage and plugging through formation of a higher-molar-volume product (molar volume of $\mathrm{CaO}=17 \mathrm{~cm}^{3} / \mathrm{mol}$, whereas molar volume of $\mathrm{CaCO}_{3}=37 \mathrm{~cm}^{3} / \mathrm{mol}$ ). CaO sorbents from naturally-occurring precursors are usually microporous. At the end of the kinetically controlled regime, diffusion through the product layer controls the reaction rate. Wei et al. [38] suggested that a mesoporous structure which maximizes porosity in the $5-20 \mathrm{~nm}$ pore size range would be less susceptible to pore pluggage, while providing sufficient surface area to ensure rapid kinetics. The modified precipitation technique [32] resulted in a mesoporous $\mathrm{CaCO}_{3}$ structure with high BET surface area $\left(60 \mathrm{~m}^{2} / \mathrm{g}\right)$. Barker [39] obtained repeated $93 \%$ conversions over 30 cycles at $629^{\circ} \mathrm{C}$ on $10 \mathrm{~nm} \mathrm{CaO}$ particles. Gupta and Fan [35] modified calcium carbonate precipitation to achieve higher (>90\%) carbonation conversions.

\section{Reactors for calcination}

To develop accurate predictive models and to simulate the calcination process, it is necessary to measure the reaction rate as a function of time and temperature. Heating rates can vary from fractions to tens of thousands of ${ }^{\circ} \mathrm{C} / \mathrm{s}$. The reaction is affected by a combination of heat transfer, mass transfer and chemical reaction, which are in turn affected to different extents by such factors as particle physical shape, heat capacity, emissivity and thermal conductivity.

A variety of reactors have been employed including induction heating, laser heating, fluidized beds, plasma and shock tubes, entrained-flow reactors, and wire-mesh reactors. An electrically heated wire-mesh reactor was first used by Loison and Chauvin [40]. They were subsequently widely employed in coal kinetics studies, e.g. by Anthony et al. [41,42], Suuberg [43] and Fong [44] at MIT; Gibbins et al. [45-47], Kandiyoti [48,49] at Imperial College, and Mill [50] at the University of New South Wales. The time of heating in this type of apparatus can be precisely controlled, and good material balances can be obtained, to an accuracy of a few percent [51]. The fundamental problems are the weighing and measurement of particle temperature during heat-up and calcination. The thermal properties and thermal response of the particles may differ significantly from the thermocouple attached to the wire mesh. These differences are important if a significant temperature gradient exists between the 
screen and the sample, in which case particle temperature is not known accurately during heating. Welding of a thermocouple to the mesh can also affect the local properties of the mesh, resulting in hot or cold spots. The diameter of the thermocouple wire and bead diameter should be comparable to the sorbent particle diameter, or smaller to reduce the ratio of the heat capacity of a thermocouple bead to that of the sorbent particle. When the sorbent particle emissivity exceeds that of the thermocouple, the sorbent may track the mesh temperature better than the thermocouple at high temperature, as radiation becomes more important than gas phase conduction [51]. It is also important, but difficult in practice, to form a thin mono-layer of sorbent on the mesh to avoid piling (i.e. more than one particle deep), which would increase the difference between the measured and actual particle temperatures.

Mill [50] reported a $0.2 \mathrm{~s}$ lag, corresponding to a $200{ }^{\circ} \mathrm{C}$ temperature gap, between the heating wire mesh and coal particle temperature for heating rates up to $1000^{\circ} \mathrm{C} / \mathrm{s}$. This difference was partly due to the difference between the signal responses of two thermocouples. The response time of the thermocouple was slower than that of the mesh due to different thermal conductivities and heat capacities. The temperature history of the coal experienced a lag, with the shape of the curve remaining similar to that of the mesh at temperatures $>400{ }^{\circ} \mathrm{C}$. A period of time with the mesh held at constant temperature is needed for the particle to reach the desired maximum temperature.

\section{Experimental system}

Fig. 1 shows the electrical circuit. A stainless steel wire mesh was used initially, but the stainless steel was then replaced by a platinum foil to avoid oxidation at high temperatures, which could affect the weight measurements.

Stainless steel screen of 325 mesh with nominal $44 \mu \mathrm{m}$ openings and $30 \mu \mathrm{m}$ wire diameter was cut into $50 \times 50 \mathrm{~mm}$ squares and symmetrically folded, whereas platinum foil of thickness $0.025 \mu \mathrm{m}$ was cut into $25 \times 50 \mathrm{~mm}$ pieces. Sorbents were spread on a $20 \times 20 \mathrm{~mm}$ rectangular section in the centre of the folded mesh or at the centre of platinum foil. The mesh or foil was held between brass clamps, and heated by direct current. A $165 \mu \mathrm{m}$ diameter type-R thermocouple bead was welded to the mesh or the foil to measure and control the mesh temperature. Industrial nitrogen sweep gas (99\%) flowed through the mesh or over the foil to remove product gas from the surface of the particles.

The DC power supply was a 12-volt automobile battery. Control of the final temperature of the mesh or foil was preset at the specified current through the mesh or foil by 5 rheostats in parallel, each with a maximum rating of $300 \mathrm{~W}(1 \Omega)$. At atmospheric pressure, a final temperature of $800-900{ }^{\circ} \mathrm{C}$ was maintained for $10-80 \mathrm{~s}$ after heating at nominal heating rates of 0.1 to $1000^{\circ} \mathrm{C} / \mathrm{s}$. The heating circuit consisted of two branches, one controlling the heating rate, whereas the second maintained the final temperature at $800-900{ }^{\circ} \mathrm{C}$. A superficial sweep gas velocity of $0.1 \mathrm{~m} / \mathrm{s}$ was used as in previous work [45-47], which showed that this is the lowest velocity to give reliable product removal at higher heating rates. Properties of the foils were relatively invariant during heating to $1500{ }^{\circ} \mathrm{C}$. To prevent sagging and buckling of the mesh, one electrode was spring-loaded so that the mesh was taut throughout the run, as in a previous study [44].

The resistivity of stainless steel is nearly 6 times that of platinum at room temperature. The available heating rate sharply decreases as the sample temperature increases. In the experiments of Anthony et al. [41] and Suuberg et al. [43], the heating rate was up to $10,000{ }^{\circ} \mathrm{C} / \mathrm{s}$ for $<0.1 \mathrm{~s}$, with $\sim 10-15 \mathrm{mg}$ of powdered coal spread in a layer one or two particles deep on a pre-weighed screen. Limestone calcination occurs mainly between 700 and $900{ }^{\circ} \mathrm{C}$. Higher temperatures make uniform heating more difficult because radiation heat losses depend on the fourth power of the absolute particle temperature. Resistivity of the material also increases with increasing temperature, necessitating a wide range of power and voltage.

Sorbents were tested in the UBC dual-environment thermogravimetric reactor (TGR) described by Laursen et al [52]. Sample particles ( 0 to $180 \mu \mathrm{m}$ ) were spread evenly in a stainless steel basket suspended in a vertical cylindrical electrical furnace of $50 \mathrm{~mm}$ inside diameter. The simulated flue gas was drawn from four cylinders containing different combinations of $\mathrm{CO}_{2}$, air, $\mathrm{N}_{2}$ and $\mathrm{SO}_{2}$. Mass flow meters measured and controlled the individual gas flows. A removable top section, including the sample holder, and a removable bottom section holding a thermocouple tube were attached to the main body of the reactor by ground joints. Samples could be unloaded and re-loaded by removing the top section. Introduced through the inlet at the bottom of the reactor, premixed gas contacted the sample

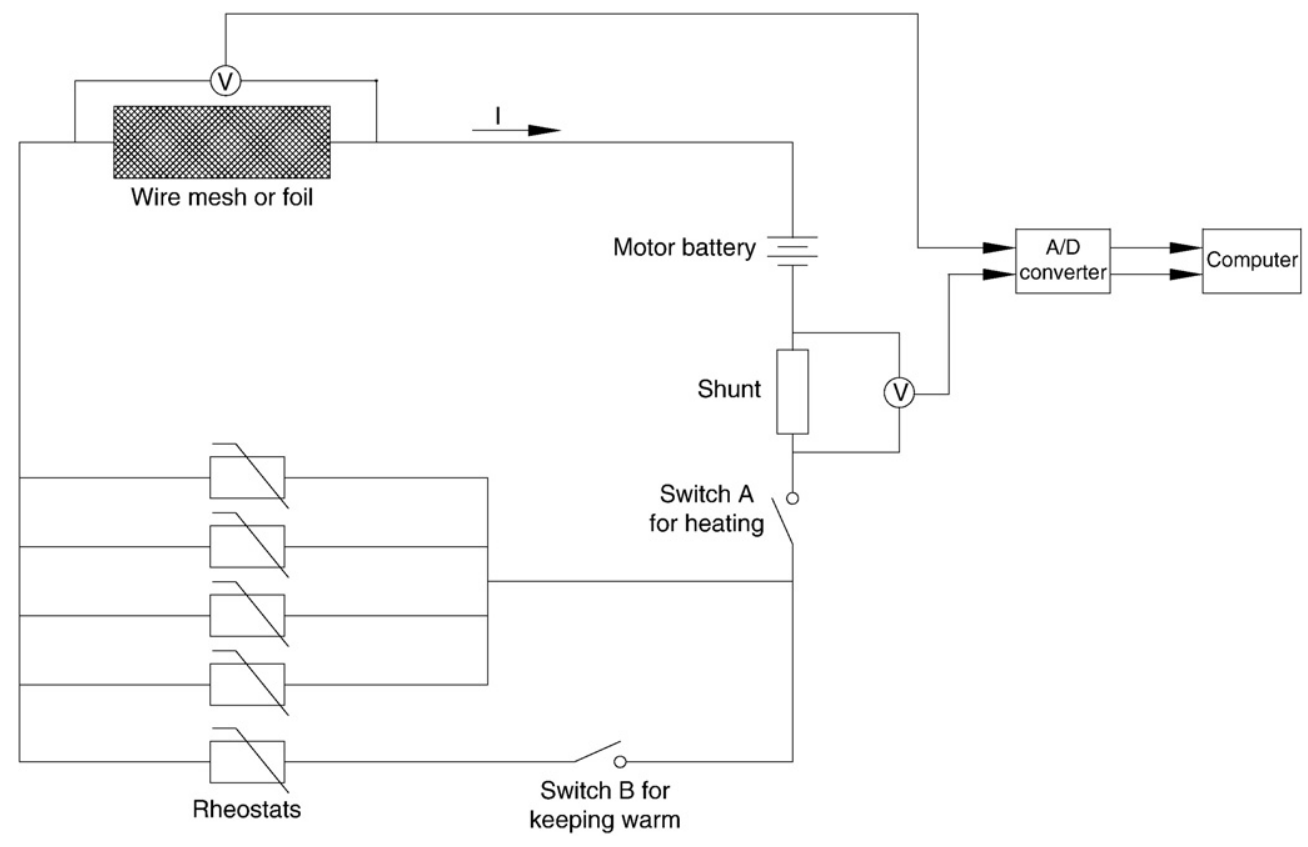

Fig. 1. Experimental heating circuit. 
particles. K-type thermocouples, inserted from the bottom, measured the temperature of the incoming gas. A pressure transducer recorded the pressure of the inlet gas upstream. Before each test, the gas stream by-passed the reactor for several minutes to adjust the inlet $\mathrm{CO}_{2}$ concentration. Calcium utilization was determined by logging sample weights using a load cell with an accuracy of $\pm 0.1 \mathrm{mg}$.

It is difficult to know the emissivity of the sample accurately for non-contact surface measurements. This may cause greater error than the difference between the temperatures of the wire mesh and the sample. The coal particle temperature can be estimated by comparing the amplitude of the radiance per unit surface area and a black-body at a single frequency or at different frequencies [51]. Pyrometry methods generally assume emissivity and radiance of the particle surface. The temperature measurement is believed to be accurate to $\pm 50{ }^{\circ} \mathrm{C}$ over the temperature range $950-1650{ }^{\circ} \mathrm{C}$. Below $950{ }^{\circ} \mathrm{C}$ the signal was too weak for accurate measurements, so the particle temperature had to be estimated from the energy conservation equation [53]. Type R (Platinum vs. Platinum/Rhodium 13\%) thermocouples are suitable for high temperatures, with a maximum temperature $>1600{ }^{\circ} \mathrm{C}$. However, their output vs. temperature is very non-linear requiring special calibration.

A $165 \mu \mathrm{m}$-diameter wire of $100 \%$ platinum and a $165 \mu \mathrm{m}$-diameter wire of $87 \%$ platinum and $13 \%$ rhodium were melted into a bead of $650 \mu \mathrm{m}$ diameter, which was then welded to the top of the mesh or foil. Effective single-point welding made it possible to avoid interference from voltage gradients through the mesh or foil.

The electrical current through the wire-mesh circuit exceeded $50 \mathrm{~A}$. Approximately $10-200 \mathrm{mg}$ of ground sorbent were carefully spread across the interior of a pre-weighed mesh or foil, which was then folded twice to form a $20 \times 50 \mathrm{~mm}$ strip. The thickness of the sample layer was 25-500 $\mu \mathrm{m}$, a compromise between efficiency of heat and mass transfer on the one hand, and weighing accuracy on the other. A crucible to hold the sample, the sample itself, the empty mesh or foil, and a glass vessel were separately weighed on an analytical balance to $\pm 0.1 \mathrm{mg}$. The Pt$\mathrm{Pt} / \mathrm{Rh} 13 \%$ thermocouple was then affixed to the top of the mesh or foil. After heating, the sample remaining on the mesh and mesh were put into a glass vessel and re-weighed to determine the weight loss due to calcination. The product was then transferred to sample bottles in a sealed nitrogen plastic bag and stored in a desiccator. The limestone composition is provided in Table 1.

\section{Results and discussion}

Limestone was rapidly heated by the electrically heating wiremesh reactor (WMR) and platinum foil reactor (PFR) to determine the effects of decomposition rate on the properties of calcium-based sorbents. The effects of heating rate $\left(0-800{ }^{\circ} \mathrm{C} / \mathrm{s}\right)$, final calcination temperature $\left(700-950^{\circ} \mathrm{C}\right)$, particle size $(90-180 \mu \mathrm{m})$ and velocity of nitrogen sweep gas $(0.1-0.51 \mathrm{~m} / \mathrm{s})$ were investigated.

Effective power and power loss are given by

$P_{\text {mesh }}=I \cdot V_{\text {mesh }}$

$P_{\text {loss }}=I \cdot\left(V_{\text {total }}-V_{\text {mesh }}\right)$

where $I=V_{\text {shunt }} / R_{\text {shunt }}$ and $R_{\text {mesh }}=V_{\text {mesh }} / I$. $R_{\text {shunt }}$ the standard shunt resistance value at room temperature was re-calibrated before each

Table 1

Metal content of Thames limestone.

\begin{tabular}{|c|c|c|c|c|c|c|c|}
\hline & $\mathrm{Ca}$ & $\mathrm{Mg}$ & $\mathrm{Al}$ & $\mathrm{Fe}$ & $\mathrm{Na}$ & K & $\mathrm{Ti}$ \\
\hline \multirow[t]{2}{*}{$\%$} & 38.87 & 0.44 & 0.21 & 0.09 & 0.07 & 0.12 & 0.01 \\
\hline & & V & & $\mathrm{Sr}$ & & & $\mathrm{Ni}$ \\
\hline $\mathrm{mg} / \mathrm{kg}$ & & $<10$ & & 179 & & & $<20$ \\
\hline
\end{tabular}

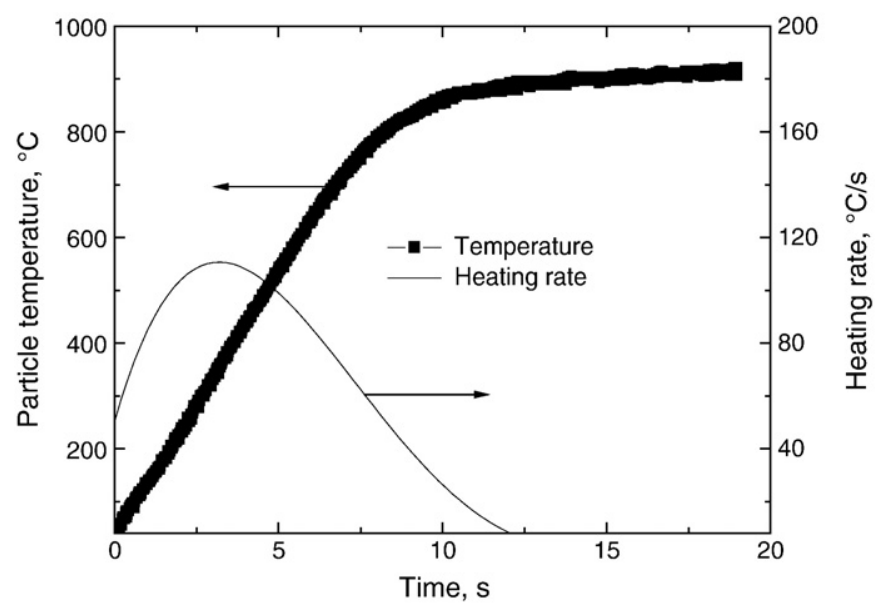

Fig. 2. Typical temperature-time trajectory during heating of $200 \mathrm{mg}$ of $63-75 \mu \mathrm{m}$ $\mathrm{CaCO}_{3}$ particles on a wire mesh.

test. $V_{\text {total }}$ is the total voltage provided by the motor battery, $V_{\text {mesh }}$ the voltage across the mesh or foil, and $V_{\text {shunt }}$ the voltage across the shunt. All voltages were recorded by the computer. $P_{\text {mesh }}$ is the effective instantaneous power dissipation for the mesh or foil, $P_{\text {loss }}$ the power loss for the heating circuit, and $I$ the current through the circuit.

Typical temperatures and heating rates are shown in Fig. 2. In this case, the wire mesh holding $200 \mathrm{mg}$ of $63-75 \mu \mathrm{m}$ diameter $\mathrm{CaCO}_{3}$ particles was heated to $900{ }^{\circ} \mathrm{C}$ at a maximum heating rate of $110{ }^{\circ} \mathrm{C} / \mathrm{s}$. The wire mesh was then maintained at $900{ }^{\circ} \mathrm{C}$ for $10 \mathrm{~s}$. During repeated heating, the weight loss of the samples was determined after different times at the same operating conditions, as shown in Fig. 3. Weight loss became rapid when the temperature reached $900{ }^{\circ} \mathrm{C}$. The calcination extent was defined and fitted by

Calcinationextent $=\frac{\text { Limestone calcined }}{\text { Initiallimestone }}=4.9 \ln (t / 0.5)$.

The original sample mass was $\sim 10$ times that in the MIT tests. The heating power and heat loss are affected significantly by radiation heat losses and by heat absorption due to the endothermic calcination reaction. The heating rate was smaller for larger samples.

Nitrogen at $1000 \mathrm{ml} / \mathrm{min}$ with $0.51 \mathrm{~m} / \mathrm{s}$ velocity swept the product $\mathrm{CO}_{2}$ during the calcination in the TGR. $\mathrm{CO}_{2}$ was added to the nitrogen flow during the carbonation stage, after opening a solenoid valve; the corresponding superficial sweep gas velocity was $0.60 \mathrm{~m} / \mathrm{s}$ with the $\mathrm{CO}_{2}$ concentration maintained at $14.4 \%$ in the

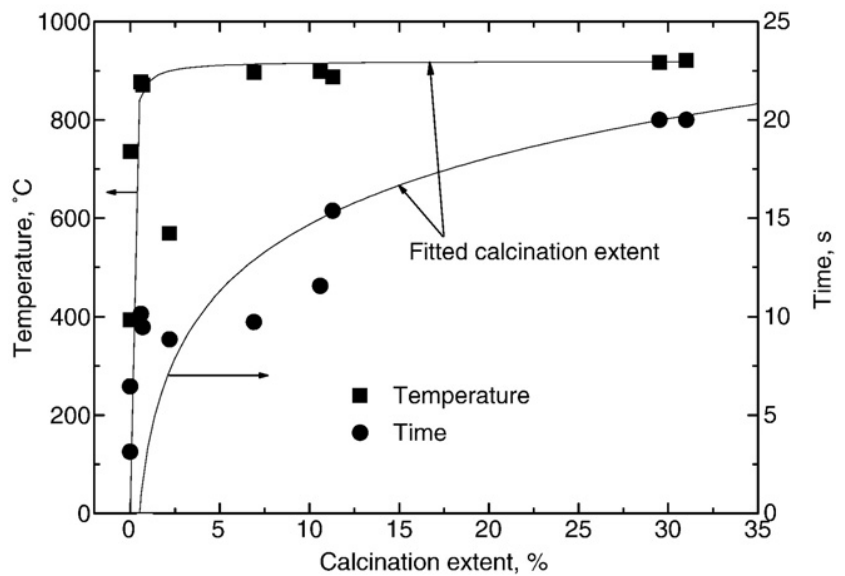

Fig. 3. Weight loss and calcination extent vs. time for maximum heating rate of $110^{\circ} \mathrm{C} / \mathrm{s}$ on a wire mesh. 
incoming gas. The initial heating rate was up to $700{ }^{\circ} \mathrm{C} / \mathrm{s}$, followed by slower heating, due to higher radiation heat losses at higher temperature. When the temperature reached $850{ }^{\circ} \mathrm{C}$, the temperature was then maintained at $850^{\circ} \mathrm{C}$ for $70 \mathrm{~s}$. A typical temperature-time trace for calcination and subsequent carbonation is plotted in Fig. 4.

From the experimental results, the highest calcium utilization was achieved for a carbonation temperature of $\sim 607^{\circ} \mathrm{C}$, as shown in Fig. 5, where

Overall Cautilization $=\underline{\text { Ca present as calcium carbonate aftercalcination and carbonation }}$ Cain original limestone

Except in one case specified below, all results in this paper are for the first stage of calcination/carbonation, i.e. there was no previous carbonation before calcining or carbonating the samples. Calcium utilization during carbonation and overall $\mathrm{Ca}$ utilization of the limestone achieved their highest levels for a carbonation temperature range of 503 to $607{ }^{\circ} \mathrm{C}$.

The initial carbonation rate decreased significantly and the reaction was very low when the carbonation temperature was $410{ }^{\circ} \mathrm{C}$. At a carbonation temperature of $708{ }^{\circ} \mathrm{C}$, the carbonation rate again significantly decreased, but reaction proceeded slowly, with the overall Ca utilization reaching $80 \%$ after $45 \mathrm{~min}$, nearing the level reached within $8 \mathrm{~min}$ for carbonation at $600{ }^{\circ} \mathrm{C}$. Carbonation was faster at the beginning, with its rate rapidly dropping from $\sim 0.60 \mathrm{~mol} /$ ( $\mathrm{mol} \mathrm{s}$ ) to $\sim 0.04 \mathrm{~mol} /(\mathrm{mol} \mathrm{s}$ ) within $300 \mathrm{~s}$ for carbonation temperatures of 503 to $607{ }^{\circ} \mathrm{C}$. The carbonation proceeded at a nearly constant low rate of $0.045 \mathrm{~mol} /(\mathrm{mol} \mathrm{s})$ for a carbonation temperature of $700{ }^{\circ} \mathrm{C}$, as shown in Fig. 6 .

Limestone calcination rates for different-diameter particles are shown in Fig. 7 for a maximum heating rate of $10^{\circ} \mathrm{C} / \mathrm{s}$. The calcination rates for the 106-125 $\mu \mathrm{m}$ and $125-150 \mu \mathrm{m}$ fractions were higher than for the smaller and larger size ranges, presumably due to complex non-linear interactions among heat transfer, mass transfer and such particle properties as internal porosity and pore size $[54,55]$.

Fig. 8 shows that limestone calcined at up to $10^{\circ} \mathrm{C} / \mathrm{s}$ could not maintain high carbonation rates. Calcination began to occur from the outer surface of particles, leading to higher $\mathrm{CaO}$ concentrations in their outer layers. Subsequent carbonation of $\mathrm{CaO}$ began at the outside, so carbonation rates fell with time as gaseous diffusion through the outer carbonate layer became rate-limiting.

Fig. 9 shows that the (stagewise) Ca utilization of $\mathrm{CaO}$, defined as

Cautilization of $\mathrm{CaO}=\frac{\text { Cacarbonated during carbonation }}{\text { Capresent as CaO before that carbonation }}$

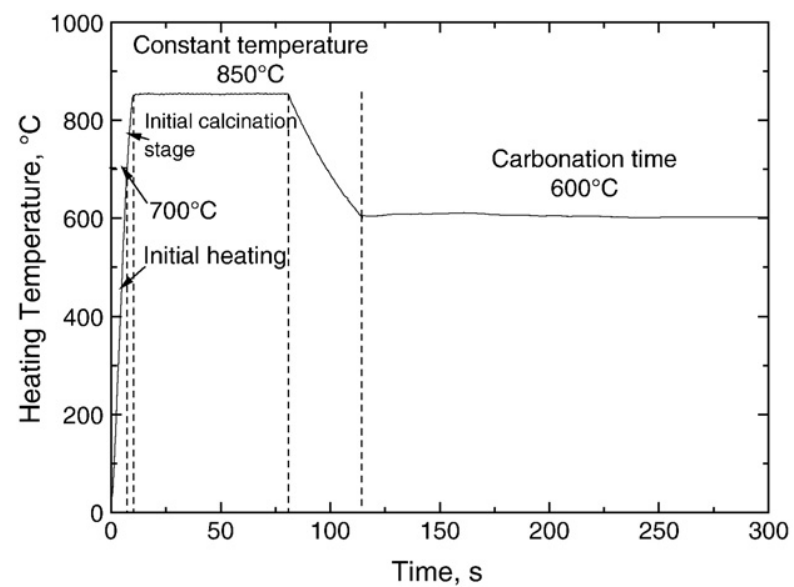

Fig. 4. Temperature-time traces during limestone calcination followed by cooling to $600{ }^{\circ} \mathrm{C}$ and carbonation.

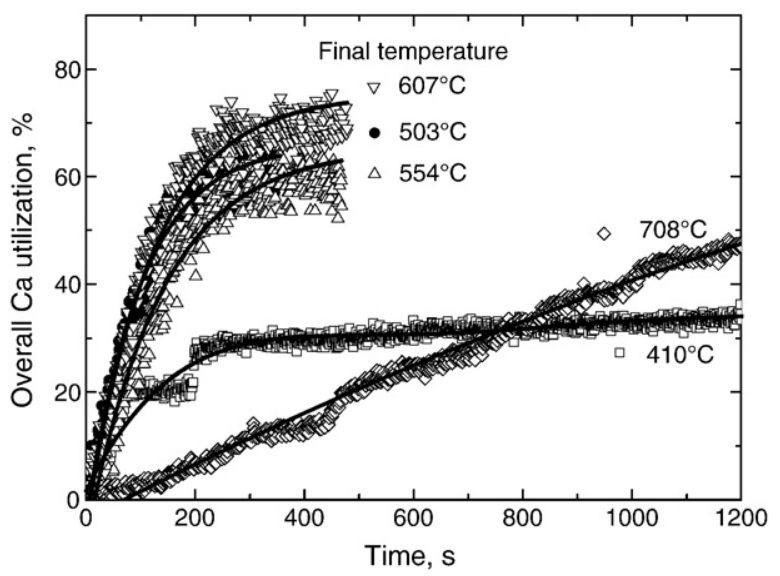

Fig. 5. Overall Ca utilization for different carbonation temperatures after maximum heating rate during calcination of $10{ }^{\circ} \mathrm{C} / \mathrm{s}$; particle diameter $75-90 \mu \mathrm{m}$; superficial sweep gas velocity 0.51 and $0.60 \mathrm{~m} / \mathrm{s}$ for calcination and carbonation, respectively.

was similar to the overall Ca utilization of limestone, defined by Eq. (7) for the different particle sizes tested, both being significantly less that the calcination extent defined by Eq. (6).

The micropore structure of $\mathrm{CaO}$ formed during calcination is very susceptible to blockage or plugging by higher-molar-volume calcium carbonate produced from carbonation as the $\mathrm{CaCO}_{3}$ product layer thickness increases. Accordingly, the carbonation rate experiences rapid attenuation.

When limestone particles smaller than $63 \mu \mathrm{m}$ were calcined at a maximum heating rate of $10{ }^{\circ} \mathrm{C} / \mathrm{s}$ for a duration sufficient to give calcination extent of $62-66 \%$, the overall Ca utilization of limestone in the subsequent carbonation was $\sim 48 \%$, as shown in Fig. 10. The overall Ca utilization of limestone after $21.3 \%$ extent of calcination was only $\sim 15 \%$. However, the corresponding Ca utilizations of $\mathrm{CaO}$ (Eq. (8)) after different extents of calcination were nearly identical and up to $\sim 70 \%$.

When $63-75 \mu \mathrm{m}$ limestone particles were $100 \%$ calcined at a maximum heating rate of $10{ }^{\circ} \mathrm{C} / \mathrm{s}$, the overall Ca utilization of the limestone increased, as shown in Fig. 11, but the $\mathrm{Ca}$ utilization of $\mathrm{CaO}$ was relatively low. The heat required for calcination tripled when the extent of calcination increased from $32.5 \%$ to $100 \%$, but the $\mathrm{Ca}$ utilization of the limestone only doubled. This indicates that increasing the calcination extent may not be the best way of improving Ca utilization.

Bortz and Flament [56] reported $70 \%$ calcination of $\mathrm{Ca}(\mathrm{OH})_{2}$ particles within the first $25 \mathrm{~ms}$ at $600{ }^{\circ} \mathrm{C}$. Mai and Edgar [11] reported

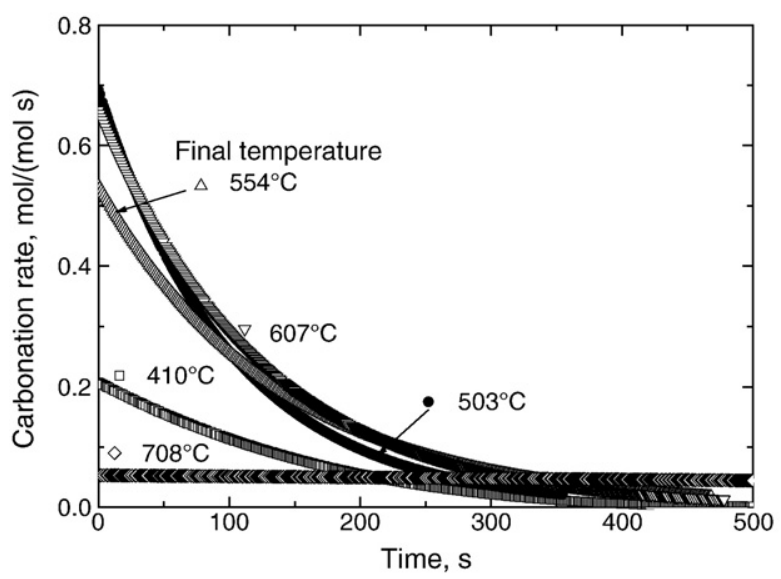

Fig. 6. Carbonation rates for different carbonation temperatures after calcination at maximum heating rate $10^{\circ} \mathrm{C} / \mathrm{s}$; particle diameter $75-90 \mu \mathrm{m}$; superficial sweep gas velocity 0.51 and $0.60 \mathrm{~m} / \mathrm{s}$ for calcination and carbonation, respectively. 


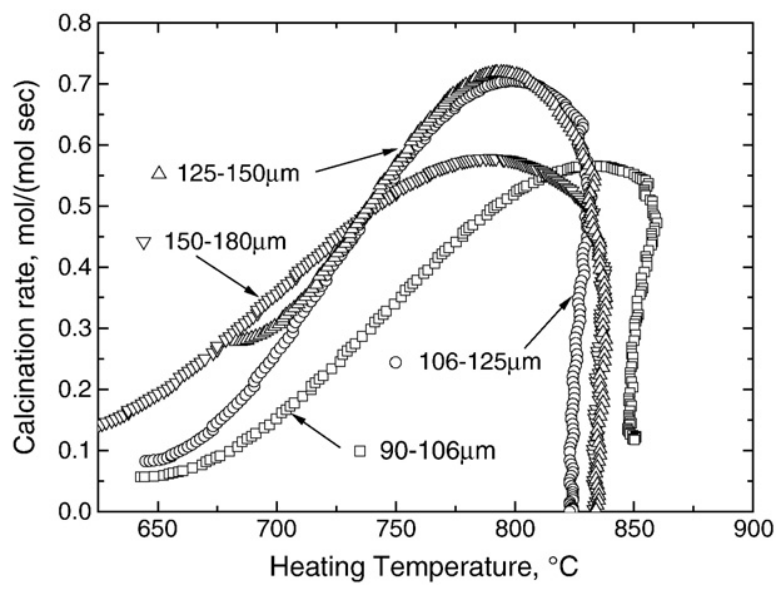

Fig. 7. Calcination rates vs. heating temperature for particles of different size ranges. Heating rate $10{ }^{\circ} \mathrm{C} / \mathrm{s}$; final temperature $850{ }^{\circ} \mathrm{C}$; superficial sweep gas velocity 0.51 and $0.60 \mathrm{~m} / \mathrm{s}$ for calcination and carbonation, respectively.

a slower decomposition rate, $35 \%$ calcination within $100 \mathrm{~ms}$ at $1152{ }^{\circ} \mathrm{C}$ for reagent-grade hydroxide powder (mass median diameter $=12.5 \mu \mathrm{m}$ ). Studies showing thermal sintering for such brief times are scarce. Very fast sintering leads to rapid reduction in surface area within 100-200 ms. Initial rapid heating adversely affects the calcination rate and extent of carbonate formation.

Limestone particles of diameter $<63 \mu \mathrm{m}$ were calcined at different heating rates to nearly the same degree of calcination. The limestone was then heated to $850^{\circ} \mathrm{C}$ in the PFR at a maximum heating rate of $300{ }^{\circ} \mathrm{C} / \mathrm{s}$ and then held at $850^{\circ} \mathrm{C}$ for $70 \mathrm{~s}$. The overall maximum Ca utilization of the limestone for carbonation at $600{ }^{\circ} \mathrm{C}$ was then $29 \%$, as shown in Fig. 12. However, the Ca utilization reached $43 \%$ when the maximum heating rate during calcination was $2.25^{\circ} \mathrm{C} / \mathrm{s}$, again indicating that the $\mathrm{Ca}$ utilization significantly increased when the calcination heating rate decreased.

When limestone particles of diameter 63-75 $\mu \mathrm{m}$ were heated to $850{ }^{\circ} \mathrm{C}$ in the PFR at up to $750{ }^{\circ} \mathrm{C} / \mathrm{s}$ (see Fig. 13) and then held at that temperature for $70 \mathrm{~s}$, the extent of calcination was $29.3 \%$, and the corresponding overall Ca utilization for carbonation was then only 9.5\%, as shown in Fig. 14. These data are much less than the calcination extent of $33.5 \%$ and overall Ca utilization of $22.1 \%$ in Fig. 14 for a greatly reduced heating rate in the TGA (plotted in Fig. 13). The corresponding (stagewise) $\mathrm{Ca}$ utilization of $\mathrm{CaO}$ was $33.8 \%$ for rapid heating, compared with $63.8 \%$ for the much lower-heating rate.

Fig. 15(b) presents results showing the effect of the initial calcination stage of $<63 \mu \mathrm{m}$ particles for two different heating

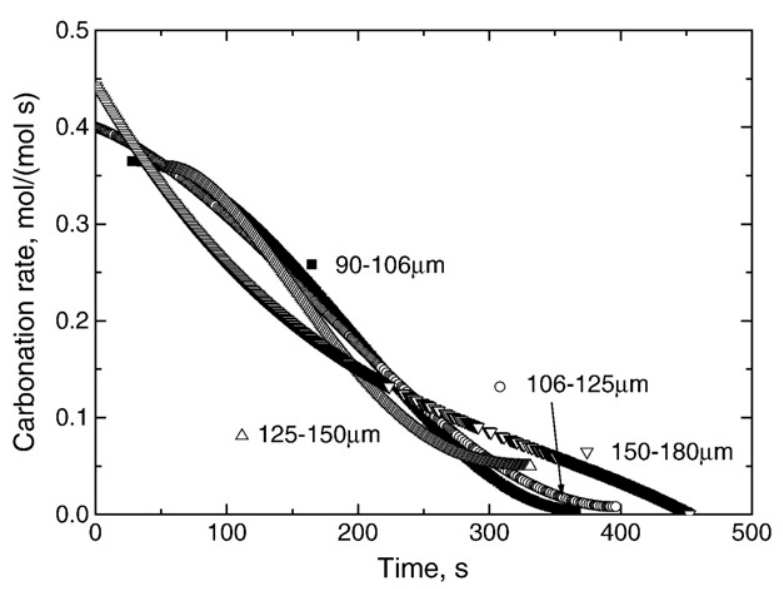

Fig. 8. Carbonation rates of particles of different size ranges. Maximum heating rate during calcination $10{ }^{\circ} \mathrm{C} / \mathrm{s}$; temperature $600{ }^{\circ} \mathrm{C}$; superficial sweep gas velocity 0.51 and $0.60 \mathrm{~m} / \mathrm{s}$ for calcination and carbonation, respectively.

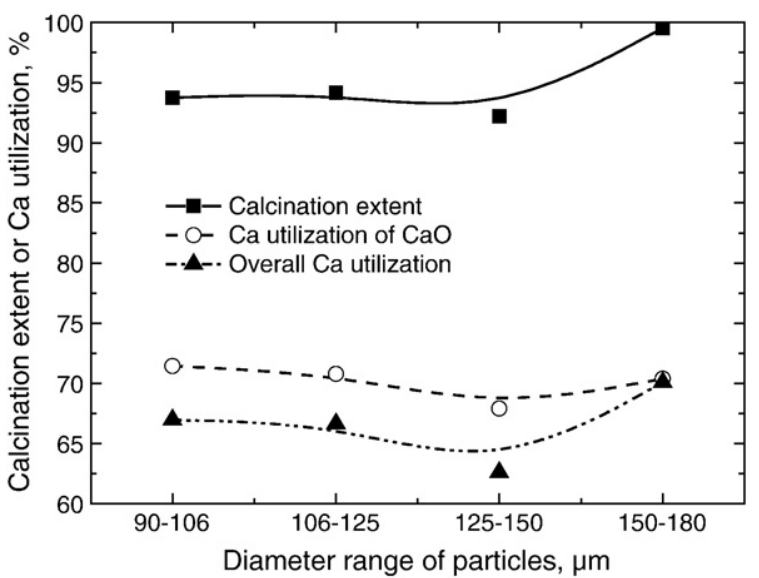

Fig. 9. Calcination extent and $\mathrm{Ca}$ utilization at different temperatures. Maximum heating rate during calcination $10{ }^{\circ} \mathrm{C} / \mathrm{s}$; final calcination temperature $850{ }^{\circ} \mathrm{C}$; carbonation temperature $600^{\circ} \mathrm{C}$; superficial sweep gas velocity 0.51 and $0.60 \mathrm{~m} / \mathrm{s}$ for calcination and carbonation, respectively.

trajectories, plotted in Fig. 15(a). Real-time sample weight and temperature were acquired during the calcination to analyze the effect of the initial heating rate on the calcination and subsequent carbonation for these two cases. Fig. 15(b) shows that calcination was significantly faster for case A, where the heating rate was nearly constant, than for case $B$, where the initial heating rate was considerably higher than the subsequent heating rate. The calcination extent then reached $\sim 70 \%$ after very different time periods. These two samples were then exposed to carbonation, with the resulting overall Ca utilization vs. time results plotted in Fig. 16. The two samples are seen to have carbonated at similar rates, with the overall Ca utilization reaching $48 \%$ during carbonation, corresponding to a Ca utilization of $\mathrm{CaO}$ of $\sim 70 \%$. Calcination was hindered during the initial heating at the higher heating rate, but had little subsequent effect on carbonation of the resulting $\mathrm{CaO}$.

The different reaction rates during sulphation of resulting $\mathrm{CaO}$ are shown in Fig. 17. The temperature was held at $800{ }^{\circ} \mathrm{C}$ during the sulphation at concentrations of $\mathrm{SO}_{2}, \mathrm{~N}_{2}$ and $\mathrm{O}_{2}$ in the gas mixture of 2237 ppmv, 3.2\% and 96.7\%, respectively, with limestone that had been $30 \%$ calcined in the WMR. There were two high-heating-rate cases, as well as one at a much lower-heating rate. In one, the sample was heated once and then held for $70 \mathrm{~s}$ at the final temperature, whereas in the other, heating, maintaining the final temperature constant and cooling occurred three times, with the cumulative constant temperature-time again being $70 \mathrm{~s}$.

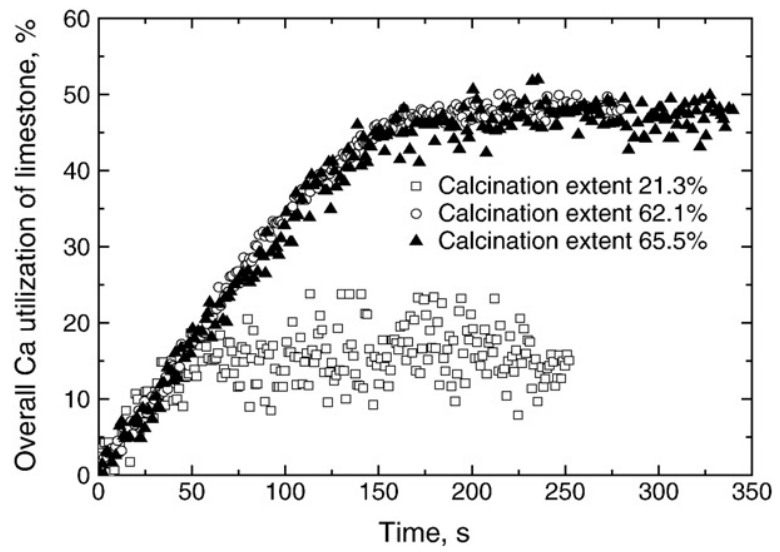

Fig. 10. Overall Ca utilization of limestone for carbonation after different extents of calcination of $<63 \mu \mathrm{m}$ limestone. Maximum heating rate during calcination $10^{\circ} \mathrm{C} / \mathrm{s}$; carbonation temperature $600^{\circ} \mathrm{C}$; superficial sweep gas velocity 0.51 and $0.60 \mathrm{~m} / \mathrm{s}$ for calcination and carbonation, respectively. 


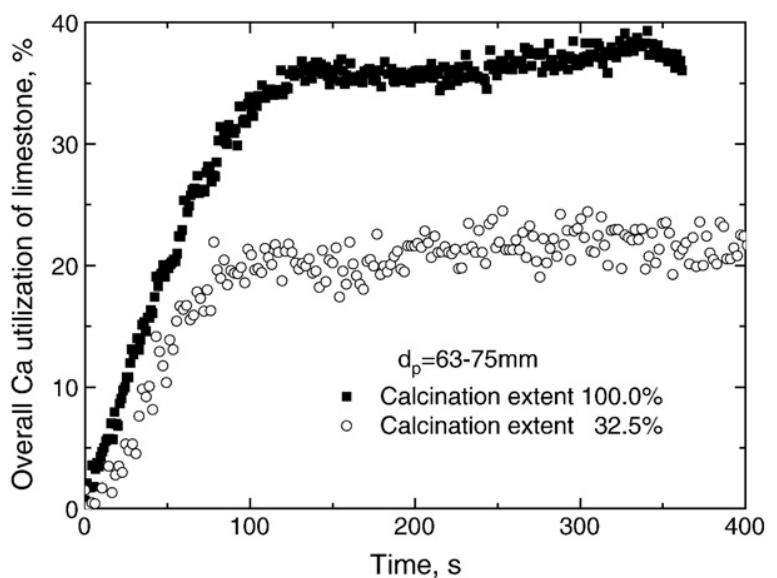

Fig. 11. Overall Ca utilization of limestone of diameter $63-75 \mu \mathrm{m}$ for different calcination extents. Maximum heating rate $10{ }^{\circ} \mathrm{C} / \mathrm{s}$; final calcination temperature $850{ }^{\circ} \mathrm{C}$; carbonation temperature $600^{\circ} \mathrm{C}$; superficial sweep gas velocity 0.51 and $0.60 \mathrm{~m} / \mathrm{s}$ for calcination and carbonation, respectively.

The sulphation rate for the rapidly resulting $\mathrm{CaO}$ was significantly lower than for the sorbent which had been calcined much more slowly. This suggests that the effect of rapid calcination is similar for carbonation and sulphation. Sulphation of limestone for the threestep discontinuous process was superior to that for a single continuous elevated temperature, as shown in Fig. 17. The reason may have been an increase of the surface area to volume ratio due to fragmentation of particles during the cyclic changes of temperature. Pores formed during the calcination of limestone may be plugged by the calcium sulphate in the outer product layer, further curbing sulphation, because the molar volume of $\mathrm{CaSO}_{4}$ is greater than that of $\mathrm{CaCO}_{3}$. However, the outer gypsum product layer may crack during repeated heating and cooling, facilitating further sulphation.

The conversion of resulting $\mathrm{CaO}$ (shown in Fig. 18) was fitted to the equation

$X=X_{u}\left[1-a \exp \left\{-k t / X_{u}\right\}\right]$

The fitted constants are listed in Table 2 for limestone particles of diameter $<63 \mu \mathrm{m}$ calcined at different heating rates. For both heating rates, the constant, $a$, is close to 1 , the value obtained by both Gupta and Fan [35] and Bhatia and Perlmutter [34].

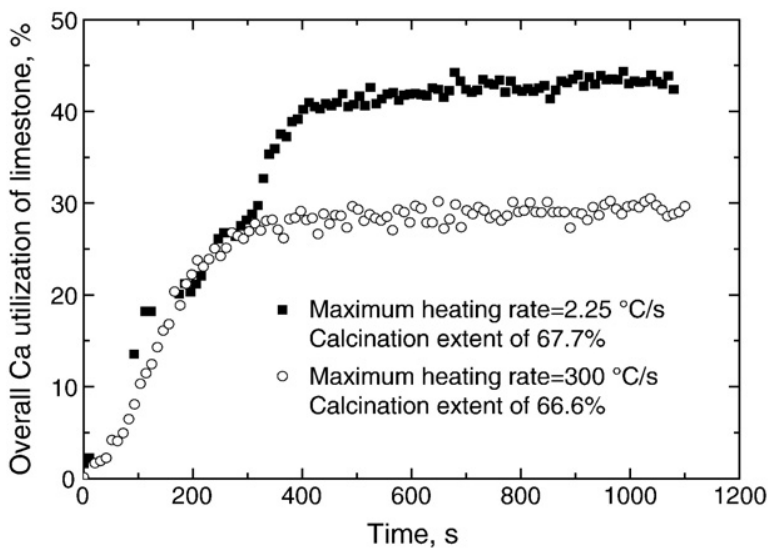

Fig. 12. Overall Ca utilization of $<63 \mu \mathrm{m}$ limestone for carbonation after high and low heating rates during calcination; final calcination temperature $850^{\circ} \mathrm{C}$; carbonation temperature $600^{\circ} \mathrm{C}$; superficial sweep gas velocity $0.1,0.51$ and $0.60 \mathrm{~m} / \mathrm{s}$ for rapid calcination, slow calcination and carbonation, respectively.

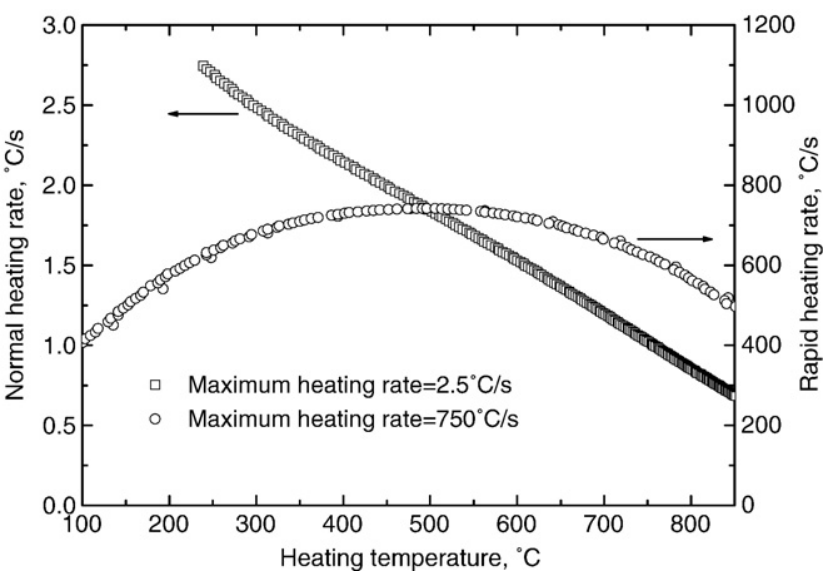

Fig. 13. Heating rate vs. temperature for two tests with $63-75 \mu \mathrm{m}$ limestone. Final calcination temperature $850^{\circ} \mathrm{C}$; carbonation temperature $600{ }^{\circ} \mathrm{C}$; superficial sweep gas velocity $0.1,0.51$ and $0.60 \mathrm{~m} / \mathrm{s}$ for rapid calcination, slow calcination and carbonation, respectively.

\section{Conclusions}

Calcination of limestone heated in an electrically heated wiremesh reactor and platinum foil reactor was studied to determine the effects of heating rate $\left(0-800^{\circ} \mathrm{C} / \mathrm{s}\right)$, calcination temperature $(700$ $\left.950{ }^{\circ} \mathrm{C}\right)$, and particle size $(0-180 \mu \mathrm{m})$ on the effectiveness of calciumbased sorbents for carbon capture via carbonation and sulphur capture via sulphation.

Of the temperatures studied, the best temperature to reach a high rate and favourable calcium utilization for carbonation was $607^{\circ} \mathrm{C}$, after calcining limestone particles at a maximum heating rate of $10{ }^{\circ} \mathrm{C} / \mathrm{s}$. Overall Ca utilization of the limestone reached its highest levels between 503 and $607{ }^{\circ} \mathrm{C}$. The rate of carbonation was faster at the beginning of the reaction and rapidly decreased from $\sim 0.6 \mathrm{~mol} /$ ( $\mathrm{mol} \mathrm{s}$ ) to $0.04 \mathrm{~mol} /(\mathrm{mol} \mathrm{s})$ within $300 \mathrm{~s}$ for carbonation temperatures of 503 to $607{ }^{\circ} \mathrm{C}$.

$\mathrm{CaO}$ produced by rapid calcination gave reduced rates of carbonation. Diffusion through the porous structure of the particles is likely to have been rate-limiting for both carbonation and sulphation. Overall Ca utilization of limestone and Ca utilization of $\mathrm{CaO}$ decreased significantly with increasing calcination heating rate. The sulphation rate was also lower for rapidly-calcined sorbent than

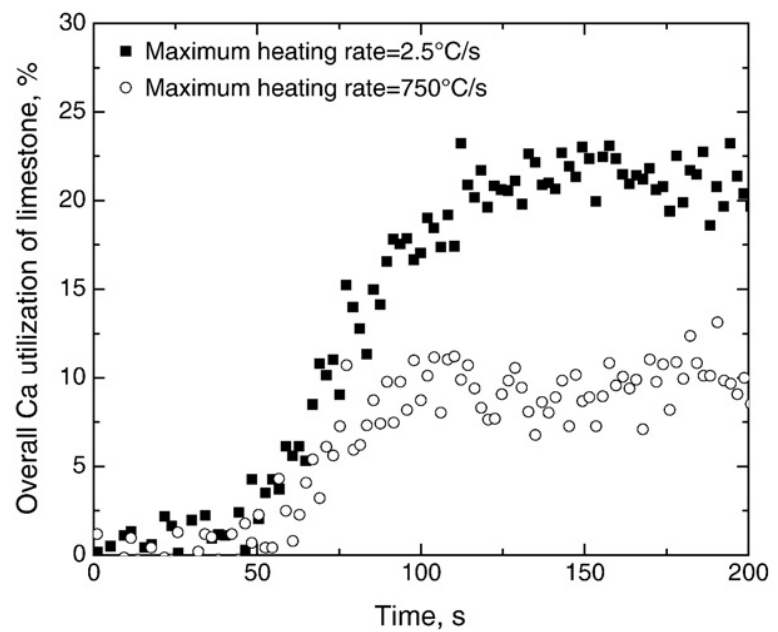

Fig. 14. Overall Ca utilization for two tests with 63-75 $\mu \mathrm{m}$ limestone. Final calcination temperature $850{ }^{\circ} \mathrm{C}$; carbonation temperature $600{ }^{\circ} \mathrm{C}$; superficial sweep gas velocity $0.1,0.51$ and $0.60 \mathrm{~m} / \mathrm{s}$ for rapid calcination, slow calcination and carbonation, respectively. For heating rates vs. temperature see Fig. 13. 
a

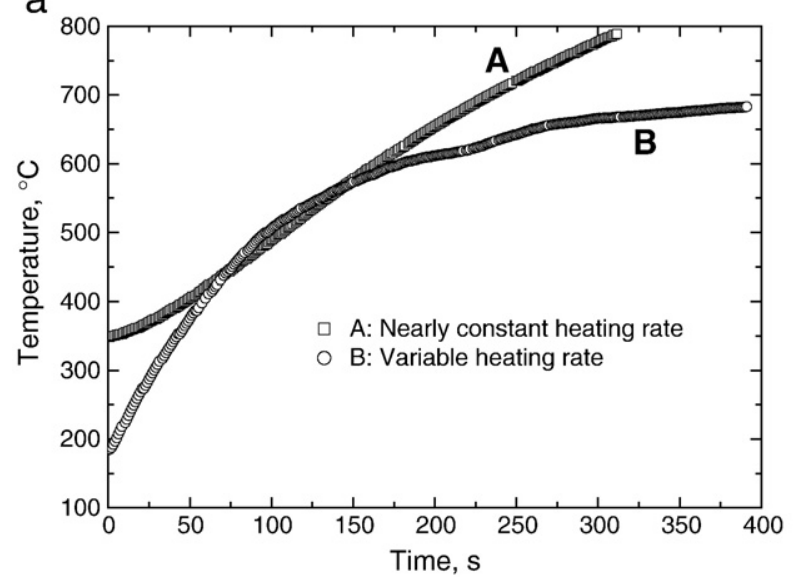

b

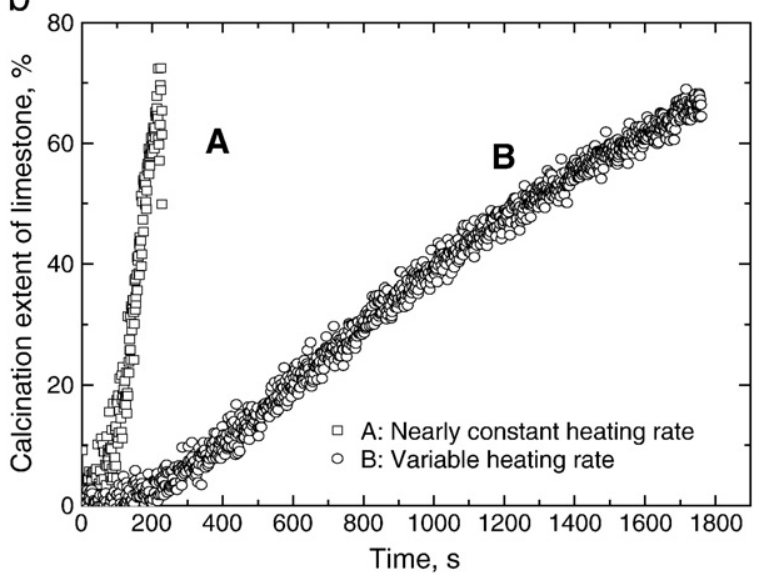

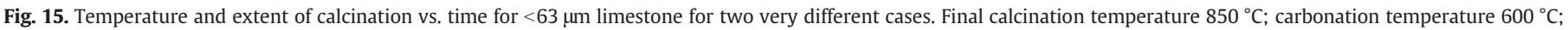
superficial sweep gas velocity 0.51 and $0.60 \mathrm{~m} / \mathrm{s}$ for calcination and carbonation, respectively.

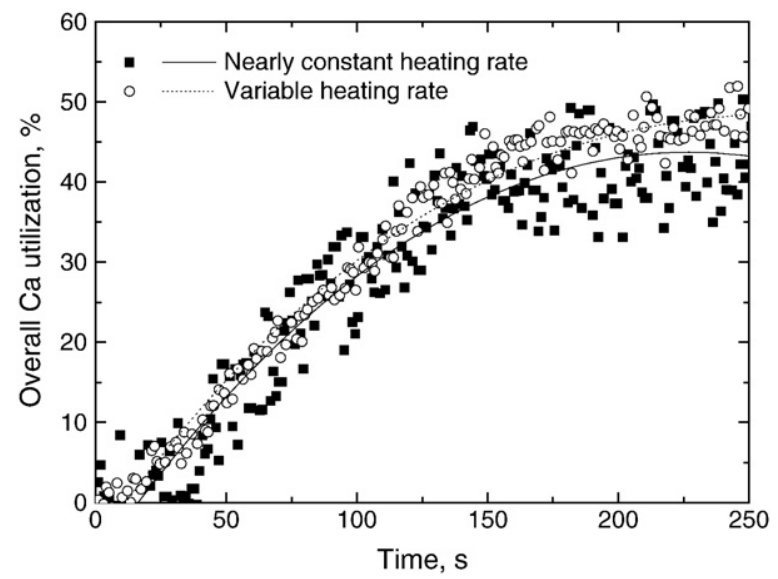

Fig. 16. Overall Ca utilization of $<63 \mu \mathrm{m}$ limestone after calcining at different heating rates as portrayed in Fig. 15. Final calcination temperature $850{ }^{\circ} \mathrm{C}$; carbonation temperature $600{ }^{\circ} \mathrm{C}$; superficial sweep gas velocity 0.51 and $0.60 \mathrm{~m} / \mathrm{s}$ for calcination and carbonation, respectively.

for slowly-calcined sorbents, i.e. the effects of rapid calcination on carbonation and sulphation were similar. Calcination is hindered during initial heating at a higher heating rate, but there is little effect on the carbonation of the resulting $\mathrm{CaO}$.

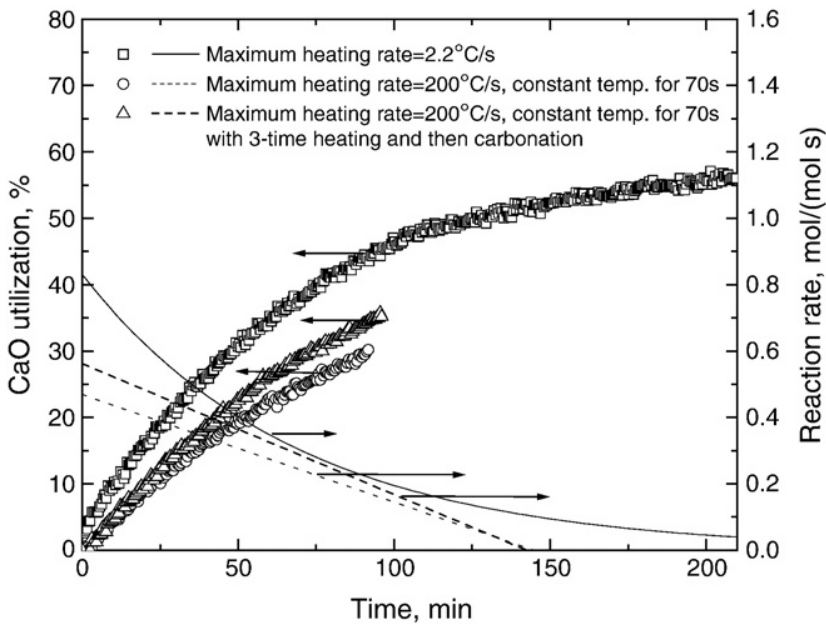

Fig. 17. Ca utilization of limestone for sulphation of limestone after three different calcination heating histories.

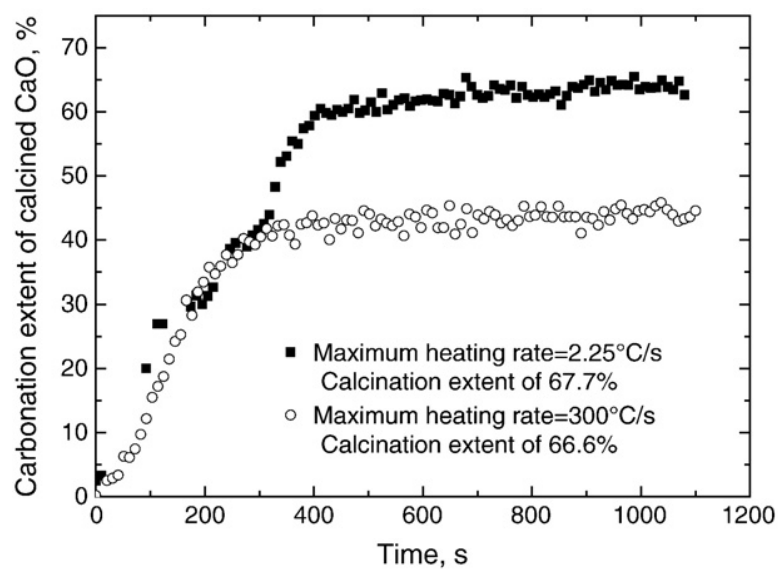

Fig. 18. Ca utilization of calcined $\mathrm{CaO}$ for $<63 \mu \mathrm{m}$ limestone particle on PFR for two different maximum heating rates; final calcination temperature $850{ }^{\circ} \mathrm{C}$; carbonation temperature $600{ }^{\circ} \mathrm{C}$; superficial sweep gas velocity 0.51 and $0.60 \mathrm{~m} / \mathrm{s}$ for calcination and carbonation respectively.

\section{Nomenclature}

a decay constant, dimensionless

$k$ rate constant for $\mathrm{CaO}$ carbonation, $\mathrm{mol} \mathrm{m}{ }^{2} /(\mathrm{s} \mathrm{Pa})$

$T$ temperature, $\mathrm{K}$

$t \quad$ time, $s$

$X_{u} \quad$ ultimate conversion of $\mathrm{CaO}, \%$

\section{Acknowledgements}

The authors are grateful to the National Natural Science Foundation of China (grant 50306026) and Guangzhou Science and Technology Bureau (grant 2006J1-C0421) for supporting C.F. Yan during this study, and to the Natural Sciences and Engineering Research Council of Canada for research funding.

Table 2

Reaction rate constant for carbonation.

\begin{tabular}{llll}
\hline $\begin{array}{l}\text { Maximum heating rate } \\
\left({ }^{\circ} \mathrm{C}\right)\end{array}$ & $\begin{array}{l}\text { Maximum } \\
\text { conversion, } X_{u}\end{array}$ & $\begin{array}{l}\text { Constant, } \\
a\end{array}$ & $\begin{array}{l}\text { Reaction rate constant, } \\
k\left(\mathrm{~s}^{-1}\right)\end{array}$ \\
\hline 2.25 & 65.5 & 1.04 & 0.29 \\
300 & 45.8 & 1.16 & 0.29 \\
\hline
\end{tabular}




\section{References}

[1] T.R. Ingraham, P. Marier, Kinetic studies on the thermal decomposition of calcium carbonate, Can. J. Chem. Eng. 41 (1963) 170-173.

[2] A.B. Fuertes, G. Marban, F. Rubiera, Kinetics of thermal decomposition of limestone particles in a fluidized bed reactor, Trans. Inst. Chem. Eng. 71A (4) (1993) 421-428.

[3] J.S. Dennis, A.N. Hayhurst, The effect of $\mathrm{CO}_{2}$ on the kinetics and extent of calcination of limestone and dolomite particles in fluidized beds, Chem. Eng. Sci. 42 (10) (1987) 2361-2372.

[4] G.D. Silcox, J.C. Kramlich, D.W. Pershing, A mathematical model for the Dash calcination of dispersed $\mathrm{CaCO}_{3}$ and $\mathrm{Ca}(\mathrm{OH})_{2}$ particles, Ind. Eng. Chem. Res. 28 (1989) 155-160.

[5] R.H. Borgwardt, Calcination kinetics and surface area of dispersed limestone particles, A.I.Ch.E. J. 31 (1) (1985) 103-111.

[6] J. Khinast, G.F. Krammer, C. Brunner, G. Staudinger, Decomposition of limestone: the influence of $\mathrm{CO}_{2}$ and particle size on the reaction rate, Chem. Eng. Sci. 51 (4) (1996) 623-634.

[7] T.R. Rao, D.J. Gunn, J.H. Bowen, Kinetics of calcium carbonate decomposition, Chem. Eng. Res. Des. 67 (1989) 38-47.

[8] N. Hu, A.W. Scaroni, Calcination of pulverized limestone particles under furnace injection conditions, Fuel 75 (1996) 177-186.

[9] K.M. Caldwell, P.K. Ghallager, D.W. Johnson, Effect of thermal transport mechanisms on the thermal decomposition of $\mathrm{CaCO}_{3}$, Thermochim. Acta 18 (1977) 15-19.

[10] M.C. Mai, T.F. Edgar, Surface area evolution of calcium hydroxide during calcination and sintering, A.I.Ch.E. J. 35 (1989) 30-36

[11] Y.H. Khraisha, D.R. Dugwell, Effect of water vapor on the calcination of limestone and raw meal in a suspension reactor, Trans. Int. Chem. Eng. 69 (1991) 76-78.

[12] J. Mu, D.D. Perlmutter, Thermal decomposition of carbonates, carboxylates, oxalates, acetates, formates, and hydroxides, Thermochim. Acta 49 (1981) 207.

[13] A. Irabien, J.R. Viguri, F. Cortabitarte, I. Ortiz, Thermal dehydration of calcium hydroxide. 2. Surface area evolution, Ind. Eng. Chem. Res. 29 (1990) 1606-1611.

[14] C.R. Milne, G.D. Silcox, D.W. Pershing, D.A. Kirchgessner, Calcination and sintering models for applications to high-temperature, short-time sulfation of calciumbased sorbents, Ind. Eng. Chem. Res. 29 (1990) 139-149.

[15] E. Garcia-Calvo, M.A. Arranz, P. Leton, Effect of impurities in the kinetics of calcite decomposition, Thermochim. Acta 170 (1990) 7-11.

[16] R.H. Borgwardt, K.R. Bruce, Effect of specific surface area on the reactivity of $\mathrm{CaO}$ with $\mathrm{SO}_{2}$, A.I.Ch.E. Ing. J. 32 (2) (1986) 239-246.

[17] D. Beruto, A.W. Searcy, Use of the Langmuir method for kinetic studies of decomposition reactions: calcite $\left(\mathrm{CaCO}_{3}\right)$, Chem. Soc. J. 70 (1974) 2145-2153 (Faraday Transaction).

[18] A. Ghosh-Dastidar, S. Mahuli, R. Agnihotri, L.S. Fan, Ultrafast calcination and sintering of $\mathrm{Ca}(\mathrm{OH})_{2}$ powder: experimental and modeling, Chem. Eng. Sci. 50 (1995) 2029-2040

[19] M. C. Mai, Analysis of simultaneous calcination, sintering, and sulfation of calcium hydroxide under furnace sorbent injection conditions. Ph.D. Thesis, Department of Chemical Engineering, University of Texas at Austin, Austin, TX, 1987.

[20] V. Fierro, J. Ada'nez, F. Garcýa-Labiano, Effect of pore geometry on the sintering of Ca-based sorbents during calcination at high temperatures, Fuel 83 (2004) 1733-1742.

[21] Y.H. Khraisha, D.R. Dugwell, Thermal decomposition of Couldon limestone in a thermogravimetric analyser, Chem. Eng. Res. Des. 67 (1989) 48-51.

[22] A.B. Fuertes, D. Alvarez, F. Rubiera, J.J. Pis, G. Marban, Simultaneous calcination and sintering model for limestone particles decomposition, Trans. Inst. Chem. Eng. 71A (1993) 69-76.

[23] J.H. Wernick, Thermal dissociation pressure of calcium carbonate, Min. Eng. 6 (1954) 730-733.

[24] K.B. Bischoff, Accuracy of the pseudo-steady-state approximation for moving boundary diffusion problems, Chem. Eng. Sci. 18 (1963) 711-715.

[25] Irfan Ar, G. Dogu, Calcination kinetics of high purity limestones, Chem. Eng. J. 83 (2) (2001) 131-137.

[26] C. Salvador, D. Lu, E.J. Anthony, J.C. Abanades, Enhancement of $\mathrm{CaO}$ for $\mathrm{CO}_{2}$ capture in an FBC environment, Chem. Eng. J. 96 (1-3) (2003) 187-195.

[27] J.C. Abanades, D. Alvarez, E.J. Anthony, D. Lu, In situ capture of $\mathrm{CO}_{2}$ in a fluidized bed combustor, Proceedings of the 17th International (ASME) Conference on Fluidized Bed Combustion, Jacksonville, Florida, USA, May 18-21, 2003, pp. 133-135, Paper no. 10.
[28] J. Wang, E.J. Anthony, J.C. Abanades, A simulation study for fluidised bed combustion of petroleum coke with $\mathrm{CO}_{2}$ capture, Proceedings of the 17th International (ASME) Conference on Fluidized Bed Combustion, ASME, New York, 2003, (FBC2003-169).

[29] T. Shimizu, T. Hirama, H. Hosoda, K. Kitano, M. Inagaki, K. Tejima, A twin fluid-bed reactor for removal of $\mathrm{CO}_{2}$ from combustion processes, Trans. Inst.Chem. Eng. 77 (Part A) (1999) 62-68.

[30] E.J. Anthony, Solid looping cycles: a new technology for coal conversion, Ind. Eng. Chem. Res. 47 (2008) 1747-1754.

[31] P. Sun, J.R. Grace, C.J. Lim, E.J. Anthony, Removal of $\mathrm{CO}_{2}$ by calcium-based sorbents in the presence of $\mathrm{SO}_{2}$, Energy Fuels 21 (2007) 163-170.

[32] D.K. Lee, An apparent kinetic model for the carbonation of calcium oxide by carbon dioxide, Chem. Eng. J. 100 (2004) 71-77.

[33] P. Sun, J.R. Grace, C.J. Lim, E.J. Anthony, Determination of intrinsic rate constants of the $\mathrm{CaO}-\mathrm{CO}_{2}$ reaction, Chem. Eng. Sci. 63 (1) (2008) 47-56.

[34] S.K. Bhatia, D.D. Perlmutter, Effect of the product layer on the kinetics of the $\mathrm{CO}_{2}$ lime reaction, A.I.Ch.E. J. 29 (1983) 79.

[35] H. Gupta, L.-S. Fan, Carbonation-calcination cycle using high reactivity calcium oxide for carbon dioxide separation from flue gas, Ind. Eng. Chem. Res. 41 (2002) 4035.

[36] A.J. Dedman, A.J. Owen, Calcium cyanamide synthesis: Part 4. The reaction $\mathrm{CaO}$ $+\mathrm{CO}_{2}=\mathrm{CaCO}_{3}$, Trans. Faraday Soc. 58 (1962) 2027-2035.

[37] D. Mess, A.F. Sarofim, J.P. Longwell, Product layer diffusion during the reaction of calcium oxide with carbon dioxide, Energy Fuels 13 (1999) 999-1005.

[38] S.-H. Wei, S.K. Mahuli, R. Agnihotri, L.-S. Fan, High surface area calcium carbonate: pore structural properties and sulfation characteristics, Ind. Eng. Chem. Res. 36 (1997) 2141-2148

[39] R. Barker, The reactivity of calcium oxide towards carbon dioxide and its use of energy storage, J. Appl. Chem. Biotech. 24 (1974) 221-227.

[40] R. Loison, R. Chauvin, Pyrolyse Rapide du Charbon, Chim. Ind. 91 (1964) 269.

[41] D.B. Anthony, J.B. Howard, H.P. Meissner, H.C. Hottel, Apparatus for determining high pressure coal-hydrogen reaction kinetics under rapid heating conditions, Rev. Sci. Instrum. 45 (1974) 992-995.

[42] D.B. Anthony, J.B. Howard, H.C. Hottel, H.P. Meissner, Rapid devolatilization and hydrogasification of bituminous coal, Fuel 55 (1976) 121-128.

[43] E.M. Suuberg, W.A. Peters, J.B. Howard, Product composition in rapid hydropyrolysis of coal, Fuel 59 (1980) 405-412.

[44] W.S. Fong, W.A. Peters, J.B. Howard, Kinetics of generation and destruction of pyridine extractables in a rapidly pyrolyzing bituminous coal, Fuel 65 (1986) 251-254.

[45] J.R. Gibbins, R. Kandiyoti, The effect of variations in time-temperature history on product distribution from coal pyrolysis, Fuel 68 (1989) 895-903.

[46] J.R. Gibbins, R.A.V. King, R.J. Wood, R. Kandiyoti, Variable-heating-rate wire-mesh pyrolysis apparatus, Rev. Sci. Instrum. 60 (1989) 1129-1139.

[47] J. Gibbins-Matham, R. Kandiyoti, Coal pyrolysis yields from fast and slow heating in a wire-mesh apparatus with a gas sweep, Energy Fuels 2 (1988) 505-511.

[48] C.J. Hindmarsh, K.M. Thomas, W.X. Wang, H.Y. Cai, A.J. Guell, D.R. Dugwell, R. Kandiyoti, A comparison of the pyrolysis of coal in wire-mesh and entrained-flow reactors, Fuel 74 (1995) 1185-1190.

[49] J.Y. Lim, I.N. Chatzakis, A. Megaritis, H.Y. Cai, D.R. Dugwell, R Kandiyoti, Gasification and char combustion reactivities of Daw Mill coal in wire-mesh and hot-rod reactors, Fuel 76 (1997) 1327-1335.

[50] C. Mill, Pyrolysis of fine coal particles at high heating rate and pressure, $\mathrm{PhD}$ thesis, University of New South Wales, Australia, Sept. 2000.

[51] P.R. Solomon, M.A. Serio, E.M. Suuberg, Coal pyrolysis: experiments, kinetic rates and mechanisms, Prog. Energy Combust. Sci. 18 (1992) 133-220.

[52] K. Laursen, W. Duo, J.R. Grace, C.J. Lim, Sulfation and reactivation characteristics of nine limestones, Fuel 79 (2000) 153-163.

[53] N. Hu, A.W. Scaroni, Fragmentation of calcium-based sorbents under high heating rate, short residence time conditions, Fuel 74 (1995) 374-382.

[54] P. Sun, J.R. Grace, C.J. Lim, E.J. Anthony, A discrete-pore-size-distribution-based gas-solid model and its application to the $\mathrm{CaO}+\mathrm{CO}_{2}$ reaction, Chem. Eng. Sci. 63 (1) (2008) 57-70.

[55] P. Sun, C.J. Lim, J.R. Grace, Cyclic $\mathrm{CO}_{2}$ capture by limestone-derived sorbent during prolonged calcination/carbonation cycling, A.I.Ch.E. J. 54 (2008) 1668-1677.

[56] S.J. Bortz, P. Flament, Recent IFRF fundamental and pilot-scale studies on the direct sorbent injection process, Proceedings: First Joint Symposium on Dry SO and Simultaneous $\mathrm{SO}_{2}$-NOx Control Technologies, 1985, pp. 17-1-17-22, Vol. 1, EPA-600/9-85/020a. 